\title{
Home-Based Enterprise and Its Impediment Factors to Self-Help House Improvement in Kampong Cikini, Jakarta
}

\author{
Joko Adianto ${ }^{1}$, Rossa Turpuk Gabe ${ }^{2}$ \\ ${ }^{1}$ Department of Architecture, Universitas Indonesia, Indonesia \\ rossa@ui.ac.id
}

\begin{abstract}
This research aims to embellish the existing literature on Home-Based Enterprise (HBE) to recuperate it as an effective solution for self-help slum improvement programs in the future. Many experts have praised HBE as one of the plausible solutions for slum alleviation through income-generating activities that will enable the underprivileged to perform self-help house improvement. However, there is a vague establishment between HBE to self-help house improvement in Kampong Cikini, as one of the notable slum settlements in Central Jakarta. Through the employment of the case study method, this research established HBE's contribution to self-help house improvement is less significant because of several impediments, which indicates the increment monthly income from HBE cannot automatically ignite the self-help house improvement. Both HBE and self-help house improvement are inseparable from socioeconomy activities in the neighborhood and cannot be comprehended as an individual economy household's activities. Therefore, specific solutions are required to overcome the mainly encountered impediments considering the established interwoven domestic and economic activities to increase the impact of HBE to self-help house improvement.
\end{abstract}

(C) 2018 IJBESR. All rights reserved.

Keywords: kampong, self-help, house, improvement, home-based enterprise, tenure security

\section{Introduction}

Slum settlement has captured worldwide attention in recent years due to its rapid growth at an alarming rate [5]. Land titling from the government is highly regarded by prominent experts such as Turner [24] and de Soto [6] as one of the optimistic policy prescriptions to reduce slum settlement growth through selfhelp house improvement by slum dwellers. Yet there is insignificant empirical evidence to declare the order has achieved the expected outcomes, especially in developing countries [17]. The rise of perceived tenure security, as coined by Van Gelder [26], emerged as an alternative source of tenure security for slum dwellers to deliver self-help house improvement and utilize their land and house for increasing their livelihood in the city. One of the utilization forms is Home-Based Enterprise (HBE).

HBE is an accepted component in the informal sector in rapidly developing cities [22]. It is defined as any business entity engaged in selling products or services operated by a selfemployed person that uses the residential property as a base of their operations [14]. Many slum dwellers are unfortunate, but manage to survive to live in the center of big cities because of their involvement in the informal economy, which is disconnected from the formal sector [2].

HBE becomes a source for income generation, especially for slum dwellers in developing countries [18]. It provides employment, income, and services for them [22] with a pool of unskilled and semi-skilled labor and makes 
underutilized labor produced at a low cost [19]. It also contributes multiplier effect in local economies by providing essential services that better suit the preferences and needs of the community [9], reduce transport costs by offering those goods and services within the settlement [22], develop and strengthen community cohesion and liveliness in the neighborhood [8]. Therefore, the house is not just a place for home-life, especially for slum dwellers [3], but it is a place of integration of domestic and economic activities [20].

Unfortunately, these multiple functions of the house are still hardly acknowledged and accepted by the government, developers, and architects because the separation of workplace and residence has been practiced since the industrial era [7].

\section{Research Aim}

Many scholars claimed that HBE enables the slum dwellers to improve the housing conditions to accommodate the activity [23], [12]. It has established by empirical studies in Sudan [11], Kenya [16], Ghana [9], Nigeria [13], and many cities in Indonesia, such as Yogyakarta [15], Malang [25] and Surabaya [1].

Tenure security has been comprehended as one of the prominent sources for self-help housing improvement, according to Turner [24] and de Soto [6] in their seminal works. The Government of Indonesia (GoI) produced Basic Agrarian Law (BAL) in 1960 and created the National Land Administration (NLA) to manages all the land registration, grants, extensions, renewals of certified titles. It aims to eliminate the dual system of land law based on the Dutch inherited western system and Indonesian customary law, including the inheritance system in religious teachings [10].

Most urban and rural inhabitants still hold Girik Letter, which was not an ownership title, but the old version of the land tax bill in the Dutch Colonial Era. The existing land rights must be converted into six types of land right under the BAL, such as Freehold or Right of Ownership, Rights to Build, Right of Strata Title Ownership on Multi-storey Building Units, Rights to Use, Right-to-Manage, and Rights to Exploit [4]. The first two forms of the right are relevant to this study. At the same time, the third is applied for multi-stories apartment's tenants, and the last four are appropriate for cultural, commercial, and agriculture activities. The conversion process encountered immense obstacles, such as a weak legal framework, limited bureaucratic capacity also expensive and time-consuming procedures [10]. Nonetheless, it is not the government regulation based landownership, but community recognition that emerges as the pivotal source of tenure security for slum dwellers and enables them to perform incremental self-help housing improvement, as argued by Van Gelder [26].

Thorough research in Yogyakarta (Indonesia) by Marsoyo [15] also African and South Asian countries by Kellett [12] and Tipple [21] have demonstrated an insignificant implication of landownership to HBE operation. Those research highlighted the absence of government regulation based land ownership does not restrict the HBE operation, even the land renters. Therefore, tenure security from community recognition based land ownership and HBE operation should enable the slum dwellers to perform self-help housing improvement.

However, although slum dwellers have community recognition based land ownership and operate HBE, the self-help housing improvement remains thwarted. Most of the physical attributes of slum settlement are still in lachrymose condition, indicating impediment factors to attaining the self-help housing improvement in slum settlement. 
This research aims to reveal the implication of tenure security to $\mathrm{HBE}$ and the encountered impediments of self-help house improvement based on tenure security and $\mathrm{HBE}$ as its prominent determinants. The result complements the existing arguments on the implication of land ownership, HBE operation, and their contributions to self-help house improvement, which may serve as considerations for the critical strategy of selfhelp house improvement in slum settlement.

\section{Material and Method}

\subsection{Research Location}

The case study area is located in the Community Association (CA) 1, Pegangsaan Sub-district, Menteng District, in the municipality of Central Jakarta, as shown in figure 1. In Menteng District, there are 906,601 residents within $48.13 \mathrm{~km} 2$. Among 5 Subdistricts in Menteng District, Pegangsaan Subdistrict is the highest density population district, where 27,934 people reside in $0.98 \mathrm{~km} 2$. Pegangsaan Sub-district consists of 8 NAs, and NA1 has been well-known as Kampong Cikini, which is identified as slum settlement.

Kampong Cikini once consisted of the housing for the workers of the National Railways Company since the Dutch colonial era. The population increased due to the irrepressible inmigration rate after the railways' overlay project in the 1960s. Most of the migrants were the traders in Cikini Market, which was built in 1962 to serve the basic needs of the Menteng elite society. This fast-growing settlement was divided into 16 RTs in the 1960s.

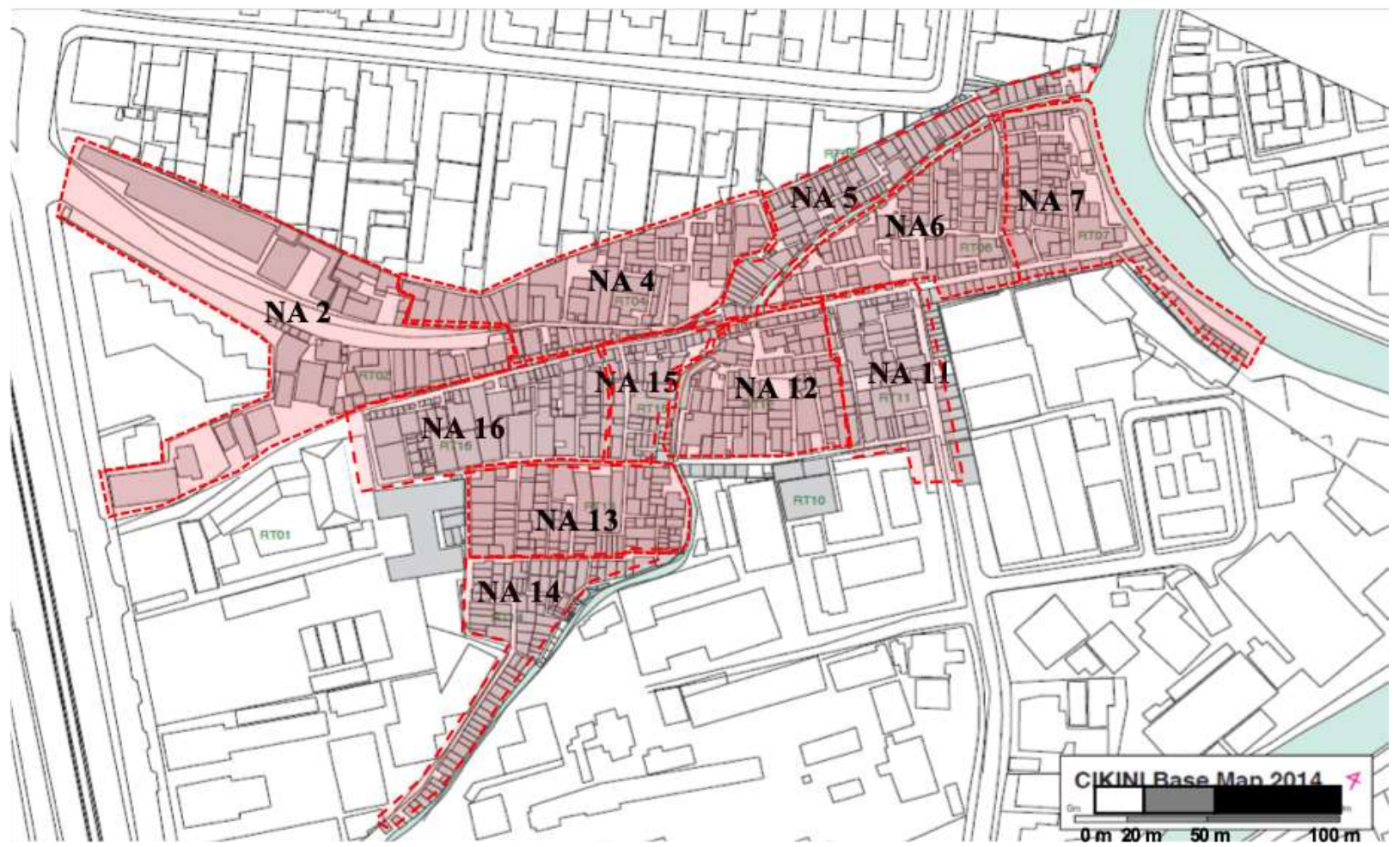

Figure 1: Location of Case Study Area: Kampong Cikini 
In the 1980s, when the Pegangsaan sub-district also emerged as a business district in the 1980s, rapid modern development turned 5 RTs into commercial and public buildings, leaves only 11 RTs in the state of Kampong. The 11 remaining RTs are RT 2, 4, 5, 6, 7, 11, 12, 13, 14, 15, and 16, where approximately 942 households live within 4.01 hectares. As the modernization development keeps on besieging, Kampong Cikini still manages to survive. This perseverance implies the urgency to select Kampong Cikini as the case study to comprehend the condition of tenure security and HBE and their implications to self-help house improvement for surviving living in the heart of the capital.

\subsection{Research Method}

This research was conducted in a qualitative method and inductive approach. In-depth interviews were addressed to respondents related to land ownership with the types of evidence, the monthly income of HBE, the implication of land ownership to $\mathrm{HBE}$, the types of made self-help house improvement, and the impediment factors of self-help house improvement which encounter the HBE owners. The gathered data and information were categorized and tabularized in the analysis stage to attain certain the impediment factors of self-help house improvement by HBE owners in the research location.

This research is divided into four stages: 1) Desk study; 2) HBEs mapping; 3) Observation and interview respondents; 4) Analysis and writing reports. The desk study consisted of reviews of the latest and essential theories of HBEs in June 2015. The investigations aimed to reach clarity of understanding and classification of HBEs focus on the type of product. Tipple [22] categorized of HBE into three categories, which are: retailing (of processed food, commodities, and unprocessed food), small-scale production (food and fresh produce, petty commodity, and specialized production), and service-oriented activities (daily and specialized service). Due to the specific context of the commodities in research location, the classification was modified into 5 (five) categories:

1. Raw foods

2. Processed Foods

3. Consumer Goods

4. Rental rooms

5. Service

In the second stage, HBE mapping was conducted for a week in early July 2015. The process was delivered intensively because some of the HBEs did not open regularly. Confirmations from neighbors were necessary to reach valid identification of HBEs in the research location. Based on HBE mapping, there were 133 HBEs in the research location. Due to the low number of HBEs population, the initial plan was to investigate all the HBEs. Before proceeding to the third stage, the structure of the interview and observation were composed. Preliminary observation and interview delivered in the third week of July 2015 and 54 respondents consented to participate in this research. Most of the HBE owners, especially rental rooms, declined to participate due to maintaining the privacy of renters and concealing their business' legality.

After receiving consent from respondents, the third stage was performed in August-September 2015. The interview was conducted with each respondent without the presence of other parties, which may compromise the data's validity. The observation was including measuring houses and visual documentation.

The fourth stage was continued after accomplished data compilation in OctoberDecember 2015. The qualitative analysis was conducted to comprehend the implication of land ownership and HBE operation to self-help house improvement with elusive considerations. 


\section{Result and Discussion}

\subsection{The Implication of Land Ownership Status to HBE Operation}

According to Indonesia's Basic Agrarian Law (BAL) Girik and Right to Build (RTB) Letter, it once has legitimations for land ownership, based on Dutch Colonial and Early Independence Era Law. While Inheritance Letter has its root in Religion Law as legitimate land ownership evidence, these letters have lost their legitimations after the National Land Agency issued Government Regulation 24/1997. It obligates the owners of those letters to register them in acquiring the acknowledged land ownership and recognition from the government. Therefore the holders of expired Girik and RTB Letters also Inheritance Letter cannot be considered legitimate evidence of land ownership from a government perspective.

All the HBE owners do not own right of ownership, which is issued by the government, as exhibits by Table-1. Most of the landowners' respondent groups $(51.43 \%)$ do not have any document to verify land ownership and depend on community recognition as evidence. Inheritance Letter becomes the second popular evidence of land ownership status owned by HBE owners (25.71\%). Land transaction documents such as Receipt of Land Transaction $(8.57 \%)$ and Contract of Sale $(2.86 \%)$ are regarded as evidence of land ownership. Only four respondents hold the expired once-eligible documents of government-issued such as Right to Build $(5.71 \%)$ and Girik Letter $(5.71 \%)$. Although the government unacknowledges those documents as eligible land ownership documents, this condition does not prevent landowners from establishing HBE.

Table 1: House Improvement According to Land Ownership and Its Evidence

\begin{tabular}{|c|c|c|c|c|c|c|c|c|c|}
\hline \multirow[b]{2}{*}{$\begin{array}{c}\text { Land } \\
\text { Ownership }\end{array}$} & \multicolumn{7}{|c|}{ Evidence of Land Ownership } & \multicolumn{2}{|c|}{ Total } \\
\hline & $\begin{array}{c}\text { Expired } \\
\text { Girik } \\
\text { Letter }\end{array}$ & $\begin{array}{l}\text { Expire } \\
\text { d RTB }\end{array}$ & $\begin{array}{c}\text { Contract } \\
\text { of Sale }\end{array}$ & $\begin{array}{c}\text { Receipt of } \\
\text { Land } \\
\text { Transaction }\end{array}$ & $\begin{array}{l}\text { Inheritanc } \\
\text { e Letter }\end{array}$ & $\begin{array}{c}\text { Recognitio } \\
\text { n from } \\
\text { Communit } \\
y\end{array}$ & None & (n) & $(\%)$ \\
\hline \multirow{3}{*}{ Owned } & 1 & 2 & 1 & 2 & 4 & 14 & - & 24 & $68.57 \%$ \\
\hline & 1 & - & - & 1 & 5 & 4 & - & 11 & $31.43 \%$ \\
\hline & 2 & 2 & 1 & 3 & 9 & 18 & - & 35 & $64.81 \%$ \\
\hline \multirow{3}{*}{$\begin{array}{l}\text { Owned by } \\
\text { Parents }\end{array}$} & 1 & - & - & - & - & 1 & - & 2 & $50.00 \%$ \\
\hline & 1 & - & - & - & - & 1 & - & 2 & $50.00 \%$ \\
\hline & 2 & - & - & - & - & 2 & - & 4 & $7.41 \%$ \\
\hline \multirow{3}{*}{ Rent } & - & - & - & - & - & - & - & - & $0,00 \%$ \\
\hline & - & - & - & - & - & - & 15 & 15 & $\begin{array}{c}100,00 \\
\%\end{array}$ \\
\hline & - & - & - & - & - & - & 15 & 15 & $27.78 \%$ \\
\hline \multirow{2}{*}{ Total } & 4 & 2 & 1 & 3 & 9 & 20 & 15 & \multirow{2}{*}{\multicolumn{2}{|c|}{54}} \\
\hline & $7.41 \%$ & $3.70 \%$ & $1.85 \%$ & $5.56 \%$ & $16.67 \%$ & $37.04 \%$ & $\begin{array}{c}27.78 \\
\%\end{array}$ & & \\
\hline
\end{tabular}

A similar condition is also experienced by the HBE owners, who establish HBE in their parent's house. Half of this respondent group depends on the community recognition of their land ownership while the other still possesses the expired Girik Letter since Dutch Colonial Era. Land renters (27.78\%) do not possess any documents of land ownership. The only evidence they have is receipt of rent payment. The owned documents and community's recognition provides tenure security for kampong dwellers to mobilize their assets, including land and house, for HBE despite the government's lack of recognized land 
ownership. It indicates formal land ownership does not have any significant implication to HBE, as many scholars have asserted.

\subsection{The Implication of HBE Operation to Self- Help House Improvement}

HBE operation contributes to the increment of self-help house improvement. 26 of 54 respondents delivered self-help house improvement because of their increment monthly income through HBE operation. All respondents are also landowners, who claimed the ownership based on the unacknowledged by the government. While all the land renters are reluctant to deliver self-help house improvement, this fact indicates the sense of land ownership plays a vital role in self-help house improvement.

There are three types of self-help house improvement: house finishing, interior partition, and vertical expansion. The first type refers to the quality improvement of the appearance of building components such as building painting, interior ceiling, floor, and roof tile. The second type covers the additional wall and openings inside the house to expand the number of rooms. While the third type encompasses the additional number of floors and house size vertically, considering the limited land size and additional stories is the only possible increment of house size.

Table 2: Types of House Improvements According to Monthly Income from HBE

\begin{tabular}{|c|c|c|c|c|c|c|}
\hline \multirow[b]{2}{*}{ Monthly Revenue ${ }^{\star}$ ) } & \multirow{2}{*}{$\begin{array}{l}\text { Types of House } \\
\text { Improvement }{ }^{\star \star} \text { ) }\end{array}$} & \multicolumn{3}{|c|}{ Reasons for House Improvements } & \multicolumn{2}{|c|}{ Total } \\
\hline & & Privacy & $\begin{array}{c}\text { Increase Trading } \\
\text { Volume }\end{array}$ & $\begin{array}{c}\text { Presti } \\
\text { ge }\end{array}$ & (n) & $(\%)$ \\
\hline \multirow{4}{*}{$<$ US\$20 } & House Finishing & - & 1 & - & 1 & $\begin{array}{r}100.00 \\
\%\end{array}$ \\
\hline & Interior Partition & - & - & - & - & $0.00 \%$ \\
\hline & Vertical Expansion & - & - & - & - & $0.00 \%$ \\
\hline & Sub Total & - & 1 & - & 1 & $3.85 \%$ \\
\hline \multirow{4}{*}{ US\$20-30 } & House Finishing & - & - & - & - & $0.00 \%$ \\
\hline & Interior Partition & 1 & - & - & 1 & $\begin{array}{r}50.00 \\
\%\end{array}$ \\
\hline & Vertical Expansion & 1 & - & - & 1 & $\begin{array}{r}50.00 \\
\% \\
\end{array}$ \\
\hline & Sub Total & 2 & - & - & 2 & $7.69 \%$ \\
\hline \multirow{4}{*}{ US\$ $\$ 30-50$} & House Finishing & - & - & - & - & $0.00 \%$ \\
\hline & Interior Partition & - & - & - & - & $0.00 \%$ \\
\hline & Vertical Expansion & 3 & - & - & 3 & $\begin{array}{r}100.00 \\
\%\end{array}$ \\
\hline & Sub Total & 3 & - & - & 3 & $\begin{array}{r}11.54 \\
\%\end{array}$ \\
\hline \multirow{4}{*}{ US\$ $\$ 0-100$} & House Finishing & - & - & 1 & 1 & $\begin{array}{r}20.00 \\
\%\end{array}$ \\
\hline & Interior Partition & 1 & - & - & 1 & $\begin{array}{r}20.00 \\
\%\end{array}$ \\
\hline & Vertical Expansion & 3 & - & - & 3 & $\begin{array}{r}60.00 \\
\%\end{array}$ \\
\hline & Sub Total & 4 & - & 1 & 5 & $\begin{array}{r}19.23 \\
\%\end{array}$ \\
\hline \multirow{4}{*}{$>$ US\$ 100} & House Finishing & - & 1 & 1 & 2 & $\begin{array}{r}13.33 \\
\%\end{array}$ \\
\hline & Interior Partition & - & 1 & - & 1 & $6.67 \%$ \\
\hline & Vertical Expansion & 9 & 3 & - & 12 & $\begin{array}{r}80.00 \\
\%\end{array}$ \\
\hline & Sub Total & 9 & 5 & 1 & 15 & $\begin{array}{r}57.69 \\
\%\end{array}$ \\
\hline \multirow[b]{2}{*}{ Total } & $(n)$ & 18 & 6 & 2 & \multirow{2}{*}{\multicolumn{2}{|c|}{26}} \\
\hline & (\%) & $69.23 \%$ & $23.08 \%$ & $7.69 \%$ & & \\
\hline
\end{tabular}


Table-2 depicts the first type is the most affordable house improvement, while the third type requires high-cost because it involves additional structure and construction. For HBE owners, who earn monthly revenue less than US\$ 20, house finishing is the only option in their self-help house improvement. As the monthly revenue increases, the other types of self-help house improvement become affordable for HBE owners. Vertical expansion, which demands high-cost expenditure, becomes one of the plausible options for house improvement when the monthly income from HBE operation has reached US\$ 30-50. Therefore, the amount of monthly income becomes a considerable determinant of house improvement types.

The reasons for self-help house improvement are also varied. Based on an in-depth interview with all HBE owners, who delivered self-help house improvement, there are three reasons: privacy, increased volume trading, and prestige. The first reason is based on their psychological needs and solving the crowding issue that encounters the household members. The second corresponds to the economic interest, where house improvement will serve the better image of $\mathrm{HBE}$ to persuade more customers. While the third refers to the social needs, where the improved house emancipates the social status of HBE owners in the family and neighborhood.

Privacy provision becomes the dominant reason $(69.23 \%)$ of self-help house improvement. The collision of domestic and economic space in the house's limited size has diminished the privacy of the household members. It proves that HBE imperils one of the basic psychological needs of household members, and the increment of monthly income has enabled them to recapture the loss of their privacy.
Self-help house improvement also benefits the HBE owners to increase their volume trading and monthly revenue (23.08\%). The improved house and economy space attracts more customers and provides better space for economic activities, such as additional rent rooms and the spatial expansion of commodity and storage. The earned monthly revenue is mobilized for capital accumulation by HBE owners to expand their business. Therefore, the self-help house improvement is designated to improve the domestic activities of household members and increase economic activities and monthly income.

Self-help house improvement also elevates the social status of kampong dwellers, according to some parts of respondents $(7.69 \%)$. All the respondents, who confirm the increment of social status, delivered the first type of self-help house improvement. The betterment of house finishing, such as house facade and other building components, represent the betterment of the household's quality and thrust their social status. The improvement encompasses the decent spatial movement of domestic and economic activities for household members and increases their social status. This increment of social status helps elevate dignity as human beings in the family and among neighbors in Kampong Cikini.

\subsection{The Impediment Factors of Self-Help House Improvement}

Despite the promising contribution to monthly income from HBE operation, it does not effectuate house improvement. There are 28 of 54 respondents $(51.85 \%)$, who operate HBE owners. Most of the respondents, who decline house improvement are the land renters, due to the absence of land ownership. 
Table 3: The Impediment Factor of Self-Help House Improvements and the Usage of Monthly Revenue

\begin{tabular}{|c|c|c|c|c|c|c|c|}
\hline \multirow[b]{2}{*}{ Land Ownership } & \multirow[b]{2}{*}{$\begin{array}{c}\text { The Usage of Monthly } \\
\text { Revenue }\end{array}$} & \multicolumn{4}{|c|}{$\begin{array}{l}\text { The Impediment Factors of Self-Help House } \\
\text { Improvement }\end{array}$} & \multicolumn{2}{|c|}{ Total } \\
\hline & & $\begin{array}{l}\text { Lack of } \\
\text { Money }\end{array}$ & $\begin{array}{c}\text { Lack of } \\
\text { Knowledge }\end{array}$ & $\begin{array}{l}\text { Lack of } \\
\text { Space }\end{array}$ & $\begin{array}{c}\text { Lack of } \\
\text { ownersh } \\
\text { ip }\end{array}$ & (n) & $(\%)$ \\
\hline \multirow{3}{*}{ Owned } & Least Priority & 8 & 2 & 1 & - & 11 & $\begin{array}{c}100.00 \\
\%\end{array}$ \\
\hline & $\begin{array}{l}\text { Buying House in Another } \\
\text { Place }\end{array}$ & - & - & - & - & - & $0.00 \%$ \\
\hline & Sub Total & 8 & 2 & 1 & - & 11 & $\begin{array}{c}39.29 \\
\%\end{array}$ \\
\hline \multirow{3}{*}{ Owned by Parents } & Least Priority & - & 1 & 1 & & 2 & $\begin{array}{c}100.00 \\
\%\end{array}$ \\
\hline & $\begin{array}{l}\text { Buying House in Another } \\
\text { Place }\end{array}$ & - & - & - & & - & $0.00 \%$ \\
\hline & Sub Total & - & 1 & 1 & & 2 & $7.14 \%$ \\
\hline \multirow{3}{*}{ Rent } & Least Priority & 1 & - & 1 & - & 2 & $\begin{array}{c}13.33 \\
\%\end{array}$ \\
\hline & $\begin{array}{l}\text { Buying House in Another } \\
\text { Place }\end{array}$ & - & - & - & 13 & 13 & $\begin{array}{c}86.67 \\
\%\end{array}$ \\
\hline & Sub Total & 1 & - & 1 & 13 & 15 & $\begin{array}{c}53.57 \\
\%\end{array}$ \\
\hline \multirow{2}{*}{ Total } & (n) & 9 & 3 & 3 & 13 & \multirow{2}{*}{\multicolumn{2}{|c|}{28}} \\
\hline & $(\%)$ & $32.14 \%$ & $10.71 \%$ & $10.71 \%$ & $46.43 \%$ & & \\
\hline
\end{tabular}

Table-3 depicts the decline of landowners to make a house improvement, mainly because of the lack of money, lack of space, and lack of knowledge. Although, most of the land renters decline to perform house improvement because of a lack of ownership.

Most of the landowners (32.14\%), who decline to improve their houses, consider the monthly income from HBE still insufficient to meet construction costs, especially for those who regard HBE as the primary means of income generation. According to this respondent group, they prefer to allocate the generated income for fundamental needs, children's education fees, cell phones, and motorcycles. The last item is a useful asset to become a part-time motorcycle driver as a self-help job opportunity to generate more income. The explanation describes house improvement becomes the least priority of the household's expenditure.

There are 3 of 28 respondents (10.71\%) claimed a lack of knowledge as the impediment to selfhelp house improvement. While the same number of respondents (10.71\%) declared a lack of space restricts their intent to deliver selfhelp housing improvement. In this case, a lack of knowledge auspicates lack of know-how with sufficient space availability. In contrast, the lack of space is a lack of spatial availability to operate domestic and economic activities during construction. Despite their different comprehensions, these two categories emphasize the apprehension towards self-help house improvement to cause disturbances to their well-established interwoven domestic, economic, and social activities of these households. Any disturbance requires problematic adjustment, especially to $\mathrm{HBE}$ operation as a source of their primary or even additional income generation.

For the respondents in the lack of knowledge category, where space availability and financial capacity do not become the issues, the ability to compose and execute self-help improvement for overcoming their substantial spatial problem becomes their primary concern. While the respondents in the lack of space category, the spatial intervention in their limited size house will impact tremendously on their well- 
established interwoven domestic, economic, and social activities of these households. Due to the lack of financial capacity to purchase or rent a house, lack of rent house, or house for sale in the surrounding neighbors, moving to other locations will jeopardize the sustenance of HBE operation, including the domestic and social life they have fabricated throughout the years.

Buying a house in another place becomes the plausible option for HBE owners, especially land renters. The lack of ownership has diminished their willingness to deliver self-help housing improvement. Although, the landowners veered their intent to provide selfhelp house improvement because of their limited capability to overcome the impediments.

\subsection{Discussion}

Despite the government's lack of acknowledged land ownership, all respondents affirm HBE as a source of income. It indicates the respondents' perceived tenure security prevails. Households' perceived rights to own and use their houses generate primary or additional income, regardless of the government's acknowledgment, as van Gelder [26] stated. This research corroborates the findings which attested to the lack of land ownership with the performance of HBE by kampong households. The role of government acknowledgment of land ownership becomes obsolete to perform this, as suggested by Turner [24] and de Soto [6] indicated in their prominent works. Therefore, this finding affirms that there is insufficient evidence to land ownership, which the government issued to HBE operations.

Many experts, such as Tipple and Ameen [23] and Kellett [12], convinced that HBE would make a significant contribution to self-help house improvement. This argument was built upon the economic perspective, where the increment income from $\mathrm{HBE}$ operation will enable the owner to deliver self-help improvement. This argument is not completely false. This research finds that nearly half of total respondents $(48.15 \%)$ performed self-help house improvement, where the amount earning monthly income determines the variety of options for the type of self-help house improvement.

However, this research discovers more than half of the respondents $(51.85 \%)$, still, decline the self-help house improvement despite the income generation occurs. There are two other reasons for this decline for landowners who live in their parent's houses, such as lack of knowledge and lack of space. Eleven landowners still contain their willingness to make house improvements. Their containments were mainly caused by the lack of money, lack of knowledge, and lack of space.

For HBE owners who live in their own and parent's land, this does not guarantee an adequate amount of monthly revenue to deliver self-help housing improvement, which is only sufficient to fulfill daily basic needs. Lack of space and knowledge are also among the inevitable constraints. The construction process will paralyze their HBEs' operation. Renting houses during the construction process is their unfavorable option due to increasing monthly expenditure also the possibility of the decrement revenue from $\mathrm{HBE}$ in the new location. Self-help house improvement requires knowledge such as design to solve most of their spatial problems within the relatively small budget and without disturbing their HBEs operations.

While all land renters decline to perform house improvement because of their lack of ownership, this research exposits the possibility of an initiative for self-help house improvement from land renters, which contradict with the aforementioned common argument. Unfortunately, the landowners disregard the intention to eliminate the land renter's sense of 
ownership and gain a higher profit by eliminating the house improvement cost.

Therefore, the increasing monthly income does not automatically initiate house improvement, as promised from various literature. Despite their monthly income increases, it does not automatically the house improvement deliver, as suggested by Tipple and Ameen [23].

During their deferment time to improving their houses, the households fabricate the wellestablished domestic, economy, and social web of activities to contend the encountered present spatial adversities through years of adaptations. Although many experts praised their remarkable ability to adapt to every changing of condition and situation, compromising the well-established domestic, economy, and social web of activities refrain because it depletes their available assets to survive. The decision of self-help house improvement bespeaks through deliberation with various considerations that involve the worst implication to their domestic, economic, and social life. Thence, self-help improvement is not linear economic matter but encompasses the entire livelihood activities of the household. It also depicts their careful adaptability to overcome the present adversities, despite many experts have praised their enormous capacity to adapt to the everchanging environment. These impediments compel the HBE owners and household members to put self-help house improvement to the least priority.

\section{Conclusion}

The presence of HBE in slum settlements, like Kampong Cikini in Jakarta, serves an extensive perspective on the meaning of the underprivileged house. It is not only a place for performing domestic activities but also economic activities essential for their life's sustenance. It requires different paradigms and design considerations for housing provision and improvement that correspond with the actual everyday life of slum dwellers such as Kampong Cikini.

Despite the lack of government's acknowledged land ownership, the kampong dwellers operate HBEs, which illustrates insufficient evidence of the implication of land ownership and HBE operation. The HBE owners utilize their houses as a space of income generator to fulfill their everyday basic needs. It amends the argument of several experts, such as de Soto [6], who claim secure tenure based on government acknowledgment of their land ownership holds an essential role in utilizing any available asset, including land and house, for financial improvement.

The increment of monthly income from HBE does not automatically stimulate the owners to improve their houses due to several obstacles. Self-help house improvement for the underprivileged is far from a trivial matter. Financial capacity for funding the improvement cannot be regarded as the only essential consideration. Still, there are many other determinant considerations because it relates to the existence of well-established domestic, economic, and social web of daily activities. Despite their highly praised adaptation ability in ever-changing circumstances, their livelihoods are vulnerable to any distractions such as self-help house improvement. These elusive implications require extensive attention to reduce the obstacles and invigorate the $\mathrm{HBE}$ owners to deliver self-help house improvement, which improves their physical condition of the deprived neighborhood.

The specific solution to each impediment is required to ignite the self-help housing improvement. A single general solution cannot be compatible with the variety of circumstantial problems, such as lack of space, lack of money, and lack of knowledge. Specific design intervention is required to solve the lack of space while the design advice can be shared to overcome the lack of knowledge. Additional 
funds from other resources such as donation or government budget to increase the monthly income through $\mathrm{HBE}$ or construction cost are considered a plausible solution for coping with the lack of money problems.

Nonetheless, the research findings are insufficient to reach profound solutions without being enriched with more variety of samples from other kampongs in Jakarta. Therefore, this research renders it possible to research in the future for a practical approach to encourage self-help house improvement in slum settlement.

\section{Acknowledgment}

Sincere gratitude is expressed to Japan Society for Promoting Science (JSPS) and Directorate of Research and Community Engagement Universitas Indonesia for funding the research. Exceptional acknowledgment is evinced to Akiko Okabe and Norihisa Shima for constructive and critical opinions as a source of the refinement of this research. The enormous contributions from Asma Nabila, Ratna Puspa Indah, and Sutanrai Abdillah during the data collecting stage are highly credited.

\section{References}

[1] Arifin, L. (2001). The Contribution of Kampung to the Sustainable Livelihood of Surabaya City Case Study Kampung Nelayan Kenjeran as Tourism District, presented at the international conference of "Sustainable Livelihood Informal Settlements in Asia, Latin America and Africa, 10 October 2001.

[2] Chen, M. (2004). Informality at work: Reconceptualizing the employment challenge. International Convention Centre, Durban, South Africa 21st - 22nd October, 2004.

[3] Coen, S.E., Ross, N.A., \& Turner, S. (2008). Without tiendas it's a dead neighborhood: The socio-economic importance of small trade stores in Cochabamba, Bolivia, Cities, 25, 327-339.

[4] Daryono. (2010). Transformation of Land Rights in Indonesia: A Mixed Private and Public Law Model. Pacific Rim Law \& Policy Journal, 19(3), 417-457.

[5] Davis, M. (2006). Planet of Slums, London: Verso.
[6] de Soto, H. (2000). The mystery of capital: why capitalism triumphs in the West and fails everywhere else. London: Bantam Press.

[7] Felstead, A., Jewson, N., \& Walters, S. (2005). Changing Places of Work, Basingstoke: Palgrave Macmillan.

[8] Gordon, R., Hudson, J., Nell, M., \& Mkhabela I. (2006). Literature Review on entrepreneurship: Housing and Housing Finance. Resource Report 3, Nairobi: Shisaka Development Services (Pty) Ltd.

[9] Gough, K.V. (2010). Continuity and Adaptability of Home-Based Enterprises-Longitudinal Study from Accra, Ghana. International Development Planning Review, 32(11), 45-70.

[10] Harsono, B. (2008). The Indonesian Agrarian Law: Historical Formation of the Land Act, Content and Implementation. Jakarta: Djambatan.

[11] Ibrahim, B. (2002). The Role of Home Based Enterprises (HBEs) in Alleviating Sudanese Urban Poverty and the Effectiveness of Policies and Programmes to Promote HBEs, Sudan Economy Research Group, Discussion Paper no 34, University of Bremen, Bremen.

[12] Kellett, P., \& Tipple, G. (2000). The home as workplace: a study of income generating activities within a domestic setting. Environment and Urbanization, 12(1), 203-213.

[13] Lawanson, T. (2012). Poverty, Home Based Enterprises and Urban Livelihoods in the Lagos Metropolis, Journal of Sustainable Development in Africa,14 (4), 158-171.

[14] Lawanson, T., \& Olanrewaju, D. (2012). The Home as Workplace: Investigating Home Based Enterprises in Low-Income Settlements of the Lagos Metropolis, Proceedings of $48^{\text {th }}$ ISOCARP Congress.

[15] Marsoyo, A. (2012). Constructing Spatial Capital: Household Adaptation Strategies in Home-Based Enterprises in Yogyakarta, Unpublished dissertation, Newcastle: University of Newcastle upon Tyne.

[16] Muraya, P. W. K. (2006). Urban planning and smallscale enterprises in Nairobi, Kenya, Habitat International, 30,127-143.

[17] Payne, G., Durand-Lasserve, A., \& Rakodi, C. (2007). Social and Economic Impacts of Land Titling Programmes in Urban and Peri-urban Areas: A Review of the Literature', in World Bank Urban Research Symposium, Washington DC, 14-16 May, 2007.

[18] Rahman, M.M. (2004). Housing affordability: Ability or Willingness? Symposium on Housing IIAffordable Dwelling, March 27-30, High Commission for the Development of Arriyadh, KSA.

[19] Raj, M., \& Nientied, P. (1990). Housing and Income in Third World Urban Development. London: Aspect Publishing.

[20] Roy, A. (2005). Urban Informality: Toward an Epistemology. Journal of the American Planning Association, 71(2), 147-158. 
[21] Tipple, G. A. (2005a). The place of home-based enterprises in the informal sector: Evidence from Cochabamba, New Delhi, Surabaya and Pretoria. Urban Studies, 42(4), 611-632.

[22] Tipple, G. A. (2005b). Pollution and Waste Production in Home-Based Enterprises in Developing Countries: Perceptions and Realities, Journal of Environmental Planning and Management, 48(2), 275298.

[23] Tipple, G. A., \& Ameen, A.S. (1999). User initiated extension activity in Bangladesh: "building slums" or area improvement? Environment and Urbanization, 11(1), 367-376.

[24] Turner, J. F. C. (1972). Freedom to Build, London: The Macmillan Company.

[25] Tutuko, P., Shen, Z. (2013). Vernacular Pattern of House Development for Home-based Enterprises in Malang, Indonesia, International review for spatial planning and sustainable development, 2 (3), 63-77.

[26] Van Gelder, J. (2010). What tenure security? The case for a tripartite view. Land Use Policy, 27, 449-456. 